\section{Salinity Tolerance of Lupinus havardii and Lupinus texensis}

\author{
Genhua Niu' ${ }^{1}$ and Denise S. Rodriguez
}

Department of Horticultural Science, Texas A\&M University, El Paso Agricultural Research and Extension Center, 1380 A\&M Circle, El Paso, TX 79927

\section{Lizzie Aguiniga \\ El Paso Community College, Research Initiative for Scientific Enhancement Program, El Paso, TX 79925}

\section{Wayne Mackay}

Department of Horticultural Science, Texas A\&M University, Dallas Agricultural Research and Extension Center, 17360 Coit Road, Dallas, TX 75252

Additional index words. bluebonnet, specialty cut flower, water reuse shown potential to be grown as a specialty cut flower (Davis et al., 1994; Picchioni et al., 2001). It has fragrant and attractive blue racemes with a length of 40 to $55 \mathrm{~cm}$ supporting 25 to 30 fully opened flowers (Mackay and Davis, 1998). In Texas, L. texensis is a hardy winter annual and is the best-known, most widely distributed member of the Lupinus genus (Davis et al., 1994). Transplants of $L$. texensis are produced for spring and fall sales, but those grown during late summer and early fall are the best for garden performance in warmer regions in the United States (Davis et al., 1994). There is no information available on the impact of saline irrigation on the growth and development of these two species. The objectives of this study were to determine the salinity threshold for marketable production of $L$. havardii and $L$. texensis and assess the effects of increasing levels of salinity on growth of these species.

\section{Materials and Methods}

Plant materials and cultural conditions. Seeds of $L$. havardii and $L$. texensis were obtained from a nursery (Plants of the Southwest, Albuquerque, N.M.), scarified with concentrated sulfuric acid for $90 \mathrm{~min}$ for L. havardii and $45 \mathrm{~min}$ for L. texensis, and sowed in a greenhouse on $10 \mathrm{Jan}$. in plug trays $\left(85 \mathrm{~cm}^{3}\right.$ per cell) filled with a mix consisting of equal parts of vermiculite, peat, and perlite on a volume basis. Seedlings were transplanted on 1 Mar. to $10-\mathrm{L}$ containers filled with Metromix 200 (Scotts Co., Marysville, Ohio). Plants were drip-irrigated as needed, based on container weight, with a nutrient solution containing $0.5 \mathrm{~g} \cdot \mathrm{L}^{-1}$ of 20N-8.6P-16.7K (Peters 20-20-20; Scotts, Allentown, PA). The air temperature in the greenhouse was 18 to $24{ }^{\circ} \mathrm{C}$ during the day and 12 to $14{ }^{\circ} \mathrm{C}$ at night during the experimental period. The daily light integral (photosynthetically active radiation) was 10 to $20 \mathrm{~mol} \cdot \mathrm{m}^{-2} \cdot \mathrm{d}^{-1}$ measured by a quantum sensor (Model QSO-SUN; Apogee Instruments, Logan, Utah). A 21X datalogger (Campbell Scientific, Logan, Utah) was used to measure temperature and light at 10 -s intervals and the hourly averages were recorded.

Treatments. Saline solutions were prepared by adding sodium chloride $(\mathrm{NaCl})$, magnesium sulfate $\left(\mathrm{MgSO}_{4} \cdot 7 \mathrm{H}_{2} \mathrm{O}\right)$, and calcium chloride $\left(\mathrm{CaCl}_{2}\right)$ at $87 \%, 8 \%$, and $5 \%$ (by weight), respectively, to the nutrient solution mentioned previously to simulate the salt composition in reclaimed municipal effluent discharged by the local water utility. Five salinity levels of 1.6 (nutrient solution, control), 3.7, 5.7, 7.6, or $9.4 \mathrm{dS} \cdot \mathrm{m}^{-1}$ electrical conductivity (EC) were created, and saline irrigation was initiated on 9 Mar. and ended on 24 May (11 weeks). There were 15 plants per treatment for each species, which were randomly placed on greenhouse benches. Five magnetic drive pumps (Model 3-MDMT-HC; Little Giant Co., Oklahoma City, Okla.) were used to pump the nutrient or saline solutions to each container through a

\footnotetext{
Received for publication 20 Nov. 2006. Accepted for publication $8 \mathrm{Feb} .2007$

This research was financially supported by the Cooperative State Research, Education and Extension Service, U.S. Department of Agriculture under Agreement No. 2005-34461-15661, El Paso Water Utilities, and Texas Agricultural Experiment Station. ${ }^{1}$ To whom reprint requests should be addressed; e-mailgniu@ag.tamu.edu
} tative growth compared with the contro (Shillo et al., 2002). Salinity stress during early reproductive stage resulted in shorter, more robust peduncles with larger inflorescences in carnation (Baas et al., 1995).

Lupinus havardii is an annual native to a narrow geographic range along the Rio Grande River in southwest Texas and has 
drip irrigation system. The amount of irrigation volume was determined by measuring the flow rates of the drip irrigation system and the water-holding capacity of the medium to obtain at least $30 \%$ leaching fraction to prevent rapid salt accumulation. Plants were irrigated when $\approx 50 \%$ of the water was depleted from the substrate by weighing five indicator containers to prevent drought stress and overwatering for all treatments.

Measurements. On termination of the experiment, plant height, two perpendicular canopy widths (after racemes were removed), visual quality, and dry weight of shoots were measured. Growth index was calculated as: growth index $=[$ height + (canopy width $1+$ canopy width 2)/2]/2. Visual quality of plants was assessed on a scale of 1 to 5 , in which $1=$ severely stunted growth with over $50 \%$ foliage salt damage (leaf necrosis, browning) or dead; $2=$ somewhat stunted growth with moderate ( $25 \%$ to $50 \%)$ foliage salt damage; $3=$ average quality with slight (less than $25 \%$ ) foliage salt damage; $4=$ good quality with acceptable growth reduction and little foliage damage; and $5=$ excellent with vigorous growth and no foliage damage. Dry weight of shoots was determined by oven-drying the tissue at $70{ }^{\circ} \mathrm{C}$ for $4 \mathrm{~d}$. The racemes of $L$. havardii were harvested weekly on shoots that were $40 \mathrm{~cm}$ or longer. Total number of racemes per plant was determined for L. texensis at harvest.

Leaf osmotic potentials $(\psi s)$ were determined by sampling a few leaves from the middle section of the shoots in the early morning (0800 to $0900 \mathrm{HR}$ ) at the end of the experiment. Leaves were sealed in a plastic bag and immediately stored in a $-80{ }^{\circ} \mathrm{C}$ freezer until analysis. Frozen leaves were thawed in a plastic bag at room temperature before sap was pressed with a Markhart leaf press (LP-27; Wescor, Logan, Utah) and analyzed using a vapor pressure osmometer (Vapro Model 5520; Wescor) to determine the leaf $\psi \mathrm{s}$. Osmometer readings $\left(\mathrm{mmol} \cdot \mathrm{kg}^{-1}\right)$ were converted to MPa using the van't Hoff equation at $25{ }^{\circ} \mathrm{C}$ (Nobel, 1991).

Five shoot samples per treatment were collected for mineral analysis of $\mathrm{Na}$ and $\mathrm{Cl}$ at the end of the experiment. Dried shoots were ground with a stainless Wiley mill and ground samples were sent to an analytic laboratory for mineral analysis (SWAT laboratory at New Mexico State University, Las Cruces, N.M.). The Na concentrations were determined by EPA method 200.7 (U.S. Environmental Protection Agency, 1983) and analyzed on an ICAP Trace Analyzer (Thermo Jarrell Ash, Franklin, Mass.). Chloride was determined by EPA method 300.0 (U.S. Environmental Protection Agency, 1983) and analyzed using an Ion Chromatograph (Dionex, Sunnyville, Calif.).

Statistical analysis. The significance of salinity treatments was analyzed by analysis of variance using SAS software (SAS Institute, Cary, N.C.). When differences were found among salinity treatments, means were separated by Student-Newman-Keuls multiple comparison at $P=0.05$. Whenever the two species were compared, $t$ test was used.

\section{Results}

After 11 weeks of treatment, L. havardii had leaf injuries at salinity levels $5.7 \mathrm{dS} \cdot \mathrm{m}^{-1}$ or greater. The $7.6 \mathrm{dS} \cdot \mathrm{m}^{-1}$ and $9.4 \mathrm{dS} \cdot \mathrm{m}^{-1}$ salinity treatments had $7 \%$ and $0 \%$ survival rates, respectively. Plants had similar visual appearance and no differences were found in cut raceme yield between the control $\left(1.6 \mathrm{dS} \cdot \mathrm{m}^{-1}\right)$ and $3.7 \mathrm{dS} \cdot \mathrm{m}^{-1}$ (Fig. 1). In contrast, L. texensis were visually acceptable (without any injuries) when irrigated at salinity up to $7.6 \mathrm{dS} \cdot \mathrm{m}^{-1}$ with a $100 \%$ survival rate at $7.6 \mathrm{dS} \cdot \mathrm{m}^{-1}$ and $15 \%$ at $9.4 \mathrm{dS} \cdot \mathrm{m}^{-1}$. Shoot growth of both species decreased as salinity levels increased, but the reduction at $5.7 \mathrm{dS} \cdot \mathrm{m}^{-1}$ and $7.6 \mathrm{dS} \cdot \mathrm{m}^{-1}$ was more severe in $L$. havardii than L. texensis. Similar observations were noted as growth index decreased with increasing salinity levels for both species. Number of flowers and visual quality in $L$. texensis were similar at salinity up to $5.7 \mathrm{dS} \cdot \mathrm{m}^{-1}$.

Shoot $\mathrm{Na}$ concentrations in $L$. havardii were significantly higher in salinity treatments $3.7 \mathrm{dS} \cdot \mathrm{m}^{-1}$ or greater compared with the control (Fig. 2). Shoot $\mathrm{Cl}$ concentrations in L. havardii was similar among 3.7, 5.7, and $7.6 \mathrm{dS} \cdot \mathrm{m}^{-1}$ and was $\approx 5$ times higher than in the control. In L. texensis, shoot $\mathrm{Na}$
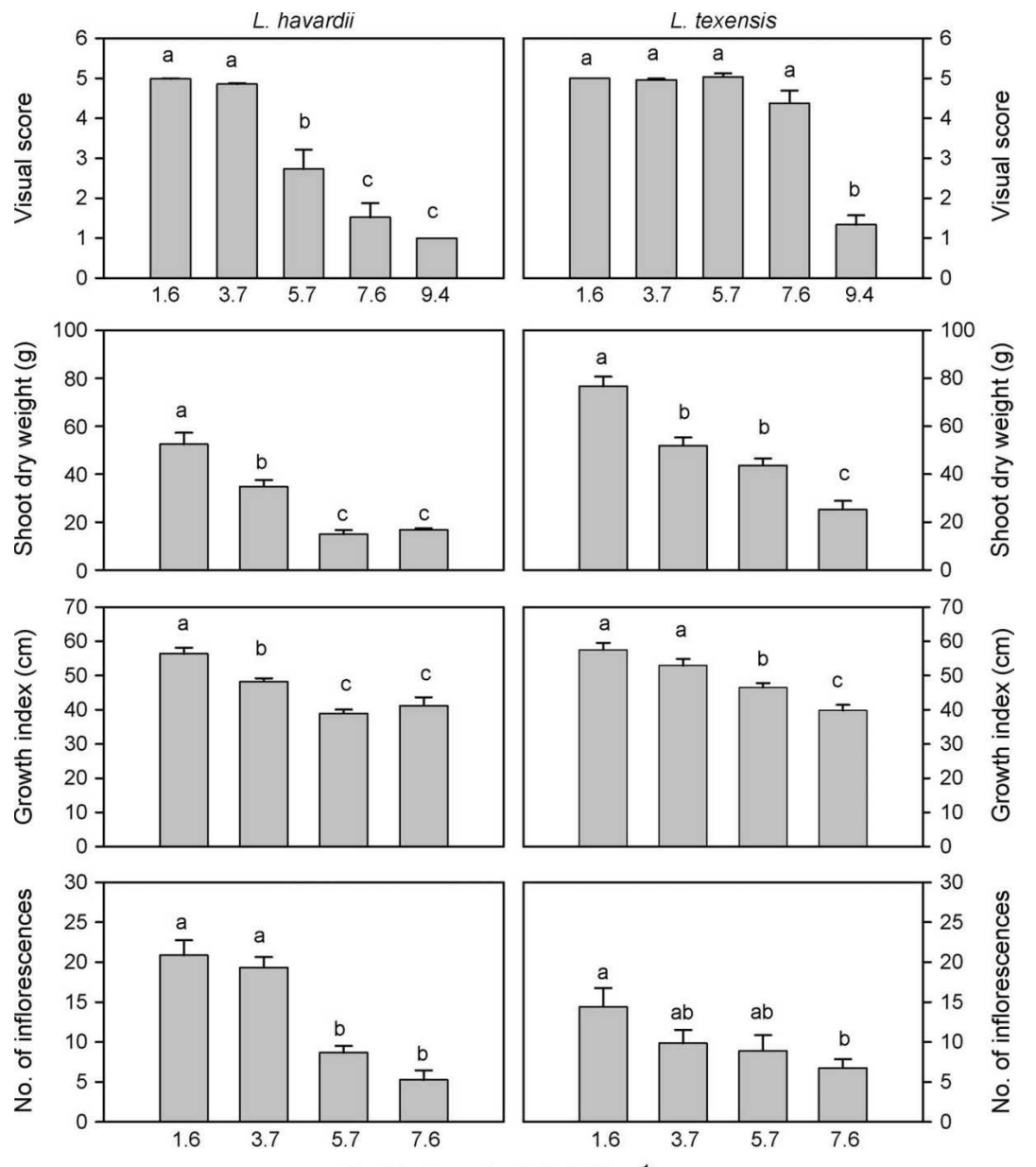

For cut flower growers, producing highquality flowers with an adequate cut length is important. In this study, we found that flower yield and quality (quantified by raceme length) were similar when irrigated with nutrient solution at $1.6 \mathrm{dS} \cdot \mathrm{m}^{-1}$ (control) and $3.7 \mathrm{dS} \cdot \mathrm{m}^{-1}$. The average EC of municipal reclaimed water is $\approx 2.0 \mathrm{dS} \cdot \mathrm{m}^{-1}$ depending on region or water source (Khurram and Miyamoto, 2005; Wu et al., 2001). This may indicate the possibility of using reclaimed water or other saline water to produce L. havardii cut flowers with little or no reduction in yield and quality as long as 


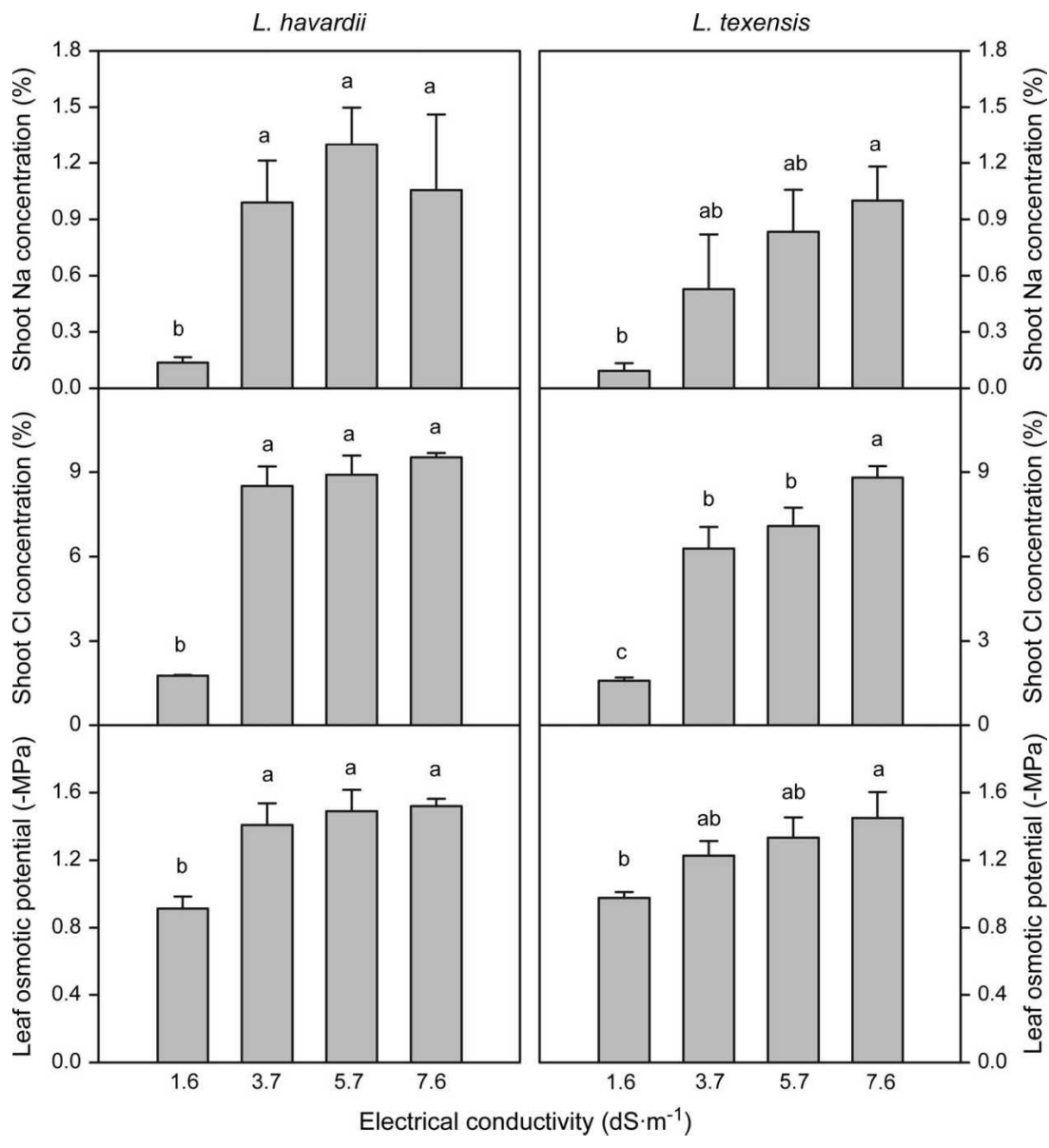

Fig. 2. Effect of salinity treatments on shoot sodium and chloride concentration (\% dry weight) and leaf osmotic potentials of Lupinus havardii and Lupinus. texensis. Means within each species followed by the same letters are not significantly different tested by Student-Newman-Keuls multiple comparison at $P=0.05$. Vertical bars represent standard errors.

the salinity of irrigation water is below 3.7 $\mathrm{dS} \cdot \mathrm{m}^{-1}$ and well-drained medium is used. Carter et al. (2005) found that saline waters dominated by sulfate and chloride salts at salinity up to $8 \mathrm{dS} \cdot \mathrm{m}^{-1}$ or higher may be used commercially to produce cut flowers of Celosia argentea (L.) Kuntze. Beneficial effects of using saline water for irrigation were also reported in lisianthus (Shillo et al., 2002) and carnation (Baas et al., 1995). Salt tolerance and threshold for producing quality cut flowers varied with plant species (Shillo et al., 2002). The slight reduction in shoot growth incited by elevated salinity at 3.7 $\mathrm{dS} \cdot \mathrm{m}^{-1}$ did not have a significant impact on yield.

Because $L$. texensis is used as a bedding plant, both growth rate and aesthetic appearance are important for bedding plant growers. Any delay in growth or visual damage may affect profit. Because the reduction in shoot growth is not commercially significant, this species can be produced using saline water at EC of up to $5.7 \mathrm{dS} \cdot \mathrm{m}^{-1}$. After installation in the landscape, visual appearance is more important than growth rate. In fact, for landscape use, a smaller or compact container plant is more preferred than a larger one if attractiveness is similar. In a landscape environment, slower growth is more desirable from a ground maintenance point of view. Therefore, non- potable water at moderate salinity levels may be used as natural growth regulators to control the excessive growth or elongation.

Some species tolerate salt stress by avoiding taking up certain types of ions or by tolerating high ion concentrations in the tissue. Wu et al. (2001) found that salttolerant plants tended to accumulate less salt in leaf tissue than less salt-tolerant plants, and a wide range of salt tolerance was found among the 10 landscape plant species examined. The small differences in salt tolerance between the two species in this study may be attributable to their uptake of $\mathrm{Na}$ and $\mathrm{Cl}$ ions. For example, shoot $\mathrm{Na}$ and $\mathrm{Cl}$ concentrations at $3.7 \mathrm{dS} \cdot \mathrm{m}^{-1}$ and $5.7 \mathrm{dS} \cdot \mathrm{m}^{-1}$ were higher in L. havardii than L. texensis. This may be why the $\psi_{\mathrm{S}}$ were lower in $L$. havardii than L. texensis at 3.7 and $5.7 \mathrm{dS} \cdot \mathrm{m}^{-1}$.

In summary, shoot growth in both species were reduced at elevated salinity levels. The threshold of salinity for producing marketable flowers of $L$. havardii is $3.7 \mathrm{dS} \cdot \mathrm{m}^{-1}$ with slight reduction in shoot growth and no visual injury. Although shoot growth in L. texensis was also reduced, there was no visible injury at salinity up to $5.7 \mathrm{dS} \cdot \mathrm{m}^{-1}$, and more plants in L. texensis survived at higher salinity $\left(7.6 \mathrm{dS} \cdot \mathrm{m}^{-1}\right.$ and $9.4 \mathrm{dS} \cdot \mathrm{m}^{-1}$ ) than $L$. havardii. Therefore, L. texensis was more salt-tolerant than L. havardii and the threshold for irriga- tion may be up to $5.7 \mathrm{dS} \cdot \mathrm{m}^{-1}$ with no visual injury.

\section{Literature Cited}

Baas, R., H.M.C. Nijssen, T.J.M. Van Den Berg, and M.G. Warmenhoven. 1995. Yield and quality of carnation (Dianthus caryophyllus L.) and gerbera (Gerbera jamesonii L.) in a closed nutrient system as affected by sodium chloride. Scientia Hort. 61:273-284.

Cameron, R.W.F., S. Wilkinson, W.J. Davies, R.S. Harrison-Murray, D. Dunstan, and C. Burgess. 2004. Regulation of plant growth in containergrown ornamentals through the use of controlled irrigation. Acta Hort. 630:305-312.

Carter, C.T., C.M. Grieve, J.A. Poss, and D.L. Suarez. 2005. Production and ion uptake of Celosia argentea irrigated with saline wastewaters. Scientia Hort. 106:381-394.

Davis, T.D., S.W. George, W.A. Mackay, and J.M. Persons. 1994. Development of Texas bluebonnets into floricultural crops. HortScience 29:1110, 1211.

Devitt, D.A., R.L. Morris, L.K. Fenstermaker, M. Baghzouz, and D.S. Neuman. 2005. Foliar damage and flower production of landscape plants sprinkle irrigated with reuse water. HortScience 40:1871-1878.

Grieve, C.M., J.A. Poss, and C. Amrhein. 2006. Response of Matthiola incana to irrigation with saline wastewaters. HortScience 41:119123.

Grieve, C.M., J.A. Poss, S.R. Grattan, P.J. Shouse, J.H. Lieth, and L. Zeng. 2005. Productivity and mineral nutrition of Limonium species irrigated with saline wastewaters. HortScience 40:654-658.

Khurram, S. and S. Miyamoto. 2005. Seedling growth, leaf injury and ion uptake response of cold-resistant palm species to salinity. J. Environ. Hort. 23:193-198.

Mackay, W.A. and T.D. Davis. 1998. 'Texas Sapphire' and 'Texas Ice' long-stem bluebonnets (Lupinus havardii). HortScience 33:348-349.

Marosz, A. 2004. Effect of soil salinity on nutrient uptake, growth, and decorative value of four ground cover shrubs. J. Plant Nutr. 27:977-989.

Niu, G. and D.S. Rodriguez. 2006a. Relative salt tolerance of five herbaceous perennials. HortScience 41:1493-1497.

Niu, G. and D.S. Rodriguez. 2006b. Relative salt tolerance of selected herbaceous perennials and groundcovers. Scientia Hort. 110:352-358.

Nobel, P.S. 1991. Physicochemical and environmental plant physiology. Academic Press Inc., San Diego, Calif.

Picchioni, G.A., M. Valenzuela-Vazquez, and S. Armenta-Sanchez. 2001. Calcium-activated root growth and mineral nutrient accumulation of Lupinus havardii: Ecophysiological and horticultural significance. J. Amer. Soc. Hort. Sci. 126:631-637.

Shannon, M.C., C.M. Grieve, S.M. Lesch, and J.H. Draper. 2000. Analysis of salt tolerance in nine leafy vegetables irrigated with saline drainage water. J. Amer. Soc. Hort. Sci. 125:658-664.

Shillo, R., M. Ding, D. Pasternak, and M. Zaccai. 2002. Cultivation of cut flower and bulb species with saline water. Scientia Hort. 92:41-54.

U.S. Environmental Protection Agency. 1983. Methods of chemical analysis of water and wastes (EPA-600/4-79-020). Cincinnati, Ohio.

Wu, L., X. Guo, and A. Harivandi. 2001. Salt tolerance and salt accumulation of landscape plants irrigated by sprinkler and drip irrigation systems. J. Plant Nutr. 24:14731490. 